\title{
Development of a Variable Number of Tandem Repeats Typing Scheme for the Bacterial Rice Pathogen Xanthomonas oryzae pv. oryzicola
}

\author{
Shuai Zhao, Lucie Poulin, Luis M. Rodriguez-R, Natalia Forero Serna, Shu-Yan Liu, Issa Wonni, Boris Szurek, \\ Valérie Verdier, Jan E. Leach, Yong-Qiang He, Jia-Xun Feng, and Ralf Koebnik
}

First, second, third, fourth, sixth, seventh, eighth, and twelfth authors: Institut de Recherche pour le Développement, UMR 186 Résistance des Plantes aux Bioaggresseurs, 34394 Montpellier, France; first, fifth, tenth, and eleventh authors: Guangxi University, State Key Laboratory for Conservation and Utilization of Subtropical Agro-bioresources, College of Life Science and Technology, Nanning, Guangxi 530004, China; sixth author: Institut de 1'Environnement et de Recherches Agricoles, Laboratoire de Phytopathologie, 01 BP 910 Bobo-Dioulasso, Burkina Faso; and eighth and ninth authors: Colorado State University, Department of Bioagricultural Sciences and Pest Management, Fort Collins 80523-1177.

Current address of L. M. Rodriguez-R: Georgia Institute of Technology, enve-omics Lab, Atlanta 30332.

Current address of N. Forero Serna: The EMMA Laboratory, Department of Biology, Macquarie University, NSW 2109 Sydney, Australia. Current address of S. Y. Liu: Science and Technology Department, Guangxi Medial University, Nanning, Guangxi 530021, China.

Accepted for publication 16 June 2012.

\begin{abstract}
Zhao, S., Poulin, L., Rodriguez-R, L. M., Serna, N. F., Liu, S.-H., Wonni, I., Szurek, B., Verdier, V., Leach, J. E., He, Y.-Q., Feng, J.-X., and Koebnik, R. 2012. Development of a variable number of tandem repeats typing scheme for the bacterial rice pathogen Xanthomonas oryzae pv. oryzicola. Phytopathology 102:948-956.

Xanthomonas oryzae pv. oryzicola is an important bacterial pathogen responsible for outbreaks of bacterial leaf streak (BLS) on rice, mostly occurring in Asia and parts of Africa. To better monitor epidemics and assess population structures, efficient tools that allow the precise identification and diagnosis of pathogenic populations are needed. In this study, we explored variable numbers of tandem repeats (VNTR) as a fast, reliable, and cost-effective molecular typing tool. Screening of three $X$. oryzae pv. oryzicola genome sequences (Philippine strain BLS256,
\end{abstract}

ABSTRACT

Bacterial leaf streak (BLS) of rice is caused by the gramnegative plant-pathogenic bacterium Xanthomonas oryzae pv. oryzicola. Since it was first discovered in the Philippines in 1918, BLS has become a widespread and economically important disease in the rice-growing areas in Asia and in parts of Africa $(12,20,35)$. The importance of BLS is increasing due to largescale cultivation of susceptible hybrid rice cultivars worldwide, especially in Southeast China, and due to efficient measures against other rice-infecting microbes (20).

Few studies have been conducted on control measures against BLS. No single resistance gene against $X$. oryzae pv. oryzicola has been identified in rice thus far (38). Only a dominant gene, Rxol from maize, has been found to mediate a non-host defense response to $X$. oryzae pv. oryzicola (37). Rxol restricts multiplication of rice pathogens harboring the recognized effector (avrRxol) when expressed as a transgene in rice (39). The search for sources of natural resistance against $X$. oryzae pv. oryzicola in rice revealed that several loci might contribute to resistance in a quantitative manner (i.e., as quantitative trait loci) (30).

Corresponding author: R. Koebnik; E-mail address: koebnik@gmx.de

http://dx.doi.org/10.1094/PHYTO-04-12-0078-R

(C) 2012 The American Phytopathological Society
Chinese strain GX01, and Malian strain MAI10) predicted 28 candidate VNTR loci. Primer pairs for polymerase chain reaction (PCR) amplification of all 28 loci were designed and applied to a panel of $20 \mathrm{X}$. oryzae pv. oryzicola strains originating from Asia and Africa. Sequencing of PCR amplicons revealed 25 robust and polymorphic VNTR loci that are shared among Asian and African X. oryzae pv. oryzicola strains. A dendrogram constructed from 25 VNTR loci indicated that most Asian strains are clearly discriminated from African strains. However, in agreement with previous reports, one strain from Mali is related to Asian strains, pointing to a possible introduction of Asian strains to the African continent. The new VNTR-based tool described here is useful for studies of population structures and epidemiological monitoring of $X$. oryzae pv. oryzicola.

Additional keyword: MLVA.
Sustainable control measures against BLS will critically depend on a deeper insight into the structure and dynamics of $X$. oryzae pv. oryzicola populations in rice-growing areas. Unfortunately, genotyping techniques for deciphering the epidemiology of $X$. oryzae pv. oryzicola have been of very limited use to date. The first comprehensive molecular and pathotypic characterization of African X. oryzae pv. oryzicola strains from Mali was performed only recently by restriction fragment length polymorphism (RFLP), repetitive sequence-based polymerase chain reaction (rep-PCR), and fluorescent amplified fragment length polymorphism (fAFLP) analysis (12). Further, a set of $X$. oryzae pv. oryzicola from three different regions of Burkina Faso and Mali in Africa were characterized by multi-locus sequence analysis (MLSA) of seven housekeeping genes and analysis of the repertoires of type III secretion system effector genes, including two discriminatory genes, avrRxol and xopW $(13,35)$. In Asia, X. oryzae pv. oryzicola strains from the Philippines with high diversity were observed (26). More recently, PCR-based DNA fingerprint analyses were used to evaluate the genetic diversity and population structure of $X$. oryzae pv. oryzicola strains from southern China using three specific primers: enterobacterial repetitive intergenic consensus (ERIC), BOX, and J3 (21).

Several methods have been developed to investigate the epidemiology of pathogens but many of them suffer from tech- 
nical limitations, such as being laborious, time-consuming, and marginally reproducible, and with limited comparability between different laboratories. Consequently, better tools for detection, typing, and tracing of the pathogens are needed. More recently, multiple loci variable number of tandem repeat (VNTR) analysis (MLVA) was introduced as a new promising technology for epidemiological surveillance of microorganisms (33). Since then, MLVA has become increasingly popular for molecular typing of bacteria $(32,34)$. Powerful MLVA schemes are available for several human pathogens, such as Bacillus anthracis, Escherichia coli, Mycobacterium tuberculosis, Pseudomonas aeruginosa, and Yersinia pestis, among others $(19,32)$. MLVA has several advantages over other bacterial genotyping methods, such as ease of performance and portability, high reproducibility and discriminatory power, rapidity, and low costs (18). However, because some VNTR loci may evolve too fast in bacterial genomes, it is necessary to evaluate several candidate loci in order to identify those which are most informative at a given temporal and geographical scale.

In 2001, shortly after the availability of the genome sequence (27), the first VNTR study of a bacterial plant pathogen, Xylella fastidiosa, was performed (9). Since then, MLVA became well established for typing of $X$. fastidiosa (6-8). The first MLVA scheme for the genus Xanthomonas has been developed for $X$. citri subsp. citri (4). Using the same scheme, the population structure of the closely related bacterium $X$. citri pv. mangiferaeindicae has been analyzed (24).

To date, only one complete genome sequence of $X$. oryzae pv. oryzicola is publicly available, corresponding to strain BLS256 from the Philippines (2). Our laboratories have access to two more $X$. oryzae pv. oryzicola genome sequences at draft level, belonging to strain MAI10 from Mali (R. Koebnik and V. Verdier, unpublished data) and strain GX01 from China (Y.-Q. He, unpublished data). These genomic resources were used to explore 28 candidate VNTR loci and to develop a high-resolution MLVA typing scheme for $X$. oryzae pv. oryzicola. Application to a panel of 20 strains of different levels of genetic relatedness originating from Asia and Africa revealed a high resolutive power of the
MLVA scheme, useful for studies of population structures and epidemiological surveillance.

\section{MATERIALS AND METHODS}

Bacterial strains, growth condition, and DNA extraction. The bacterial strains used in this study are listed in Table 1, including those whose genomes have been sequenced: $X$. oryzae pv. oryzicola Philippine strain BLS256 (2), Malian strain MAI10 (R. Koebnik and V. Verdier, unpublished data), and Chinese strain GX01 (Y.-Q. He, unpublished data). All the sequenced strains were used as controls for PCR. X. oryzae pv. oryzicola strains were grown in peptone-sucrose agar (PSA) medium (10 $\mathrm{g}$ of peptone, $10 \mathrm{~g}$ of sucrose, $1 \mathrm{~g}$ of glutamic acid, and $16 \mathrm{~g}$ of agar per liter of $\mathrm{H}_{2} \mathrm{O}$ ) at $28^{\circ} \mathrm{C}$. Genomic DNA was extracted from bacterial colonies on the PSA plates cultured for $48 \mathrm{~h}$ using the Wizard genomic purification kit from Promega (Promega, Paris). The quality and quantity of DNA were evaluated by agarose gel electrophoresis and spectrophotometry (Nanodrop ND-1000; Nanodrop Technologies, Wilmington, DE).

Prediction of VNTR loci and primer design. The complete genome sequence of the Philippine $X$. oryzae pv. oryzicola strain BLS256 (GenBank accession number CP003057) and two draft genome sequences from Malian $X$. oryzae pv. oryzicola strain MAI10 and Chinese strain GX01 were scrutinized for the presence of the candidate VNTR loci using a web-based prediction pipeline (http://www.biopred.net/VNTR/). Parameters were set as follows: Algorithm TRF (tandem repeat finder) (1), region length of 30 to $1,000 \mathrm{bp}$, unit length of 5 to $9 \mathrm{bp}$, at least six copies, and an identity of a least $80 \%$ between adjacent repeats. Predicted VNTR loci were grouped according to their shared 500-bp flanking regions and dubbed with the first letter of the strain designation, followed by a number reflecting the order along the genome sequence.

Homologous 500-bp regions next to the predicted VNTR loci were extracted from all three $X$. oryzae pv. oryzicola genome sequences and aligned using MUSCLE (http://www.ebi.ac.uk/

TABLE 1. Bacterial strains (Xanthomonas oryzae pv. oryzicola) used in this study

\begin{tabular}{|c|c|c|c|c|c|c|c|c|c|c|c|c|}
\hline \multirow[b]{3}{*}{ Strains } & \multirow[b]{3}{*}{ Country, location } & \multirow[b]{3}{*}{ Year } & \multirow[b]{3}{*}{ Host } & \multicolumn{8}{|c|}{ Haplotype $^{\mathrm{a}}$} & \multirow[b]{3}{*}{ Resources $^{\mathrm{b}}$} \\
\hline & & & & \multicolumn{4}{|c|}{ RFLP } & \multirow[b]{2}{*}{ rep-PCR } & \multirow{2}{*}{$\begin{array}{l}\text { Eric- } \\
\text { PCR }\end{array}$} & \multirow[b]{2}{*}{ AFLP } & \multirow[b]{2}{*}{ VNTR } & \\
\hline & & & & IS 1112 & avrXa10 & IS 1113 & Xoo1762 & & & & & \\
\hline \multicolumn{13}{|l|}{ Diversity panel } \\
\hline BLS256 (CFBP7109) & Philippine & 1985 & Oryza sativa & $\ldots$ & $\ldots$ & $\ldots$ & $\ldots$ & $\ldots$ & $\ldots$ & $\ldots$ & 1 & C. Vera Cruz \\
\hline LMG797 (CFBP2286) & Malaysia & 1964 & O. sativa & 25 & 25 & 17 & 6 & 19 & 14 & 3 & 2 & CFBP \\
\hline NCPPB2921 (CFBP2287) & Malaysia & 1973 & O. sativa & 26 & 26 & 17 & 6 & 20 & 14 & & 3 & CFBP \\
\hline UPB497 & Malaysia & & O. sativa & & 26 & & & 26 & 20 & 3 & 4 & C. Bragard \\
\hline GX01 & Guangxi, China & 2005 & O. sativa sp. indica & $\ldots$ & $\ldots$ & $\ldots$ & $\ldots$ & $\ldots$ & $\ldots$ & $\ldots$ & 5 & Y.Q. He \\
\hline GX07 & Guangxi, China & 2008 & O. sativa var. Teyou 838 & $\ldots$ & $\ldots$ & $\ldots$ & $\ldots$ & $\ldots$ & $\ldots$ & $\ldots$ & 6 & J. X. Feng \\
\hline FJ15 & Fujian, China & 2008 & O. sativa var. Yongyou 6 & $\ldots$ & $\ldots$ & $\ldots$ & $\ldots$ & $\ldots$ & $\ldots$ & $\ldots$ & 7 & J. X. Feng \\
\hline MAI3 (CFBP7326) & Niono, Mali & 2004 & O. sativa var. Wassa & 27 & 27 & 18 & 7 & 21 & 15 & 3 & 8 & V. Verdier \\
\hline MAI4 (CFBP7327) & Niono, Mali & 2004 & O. sativa var. Nonioka & 28 & 28 & 19 & 8 & 22 & 16 & $\ldots$ & 9 & V. Verdier \\
\hline MAI5 (CFBP7328) & Niono, Mali & 2004 & O. sativa var. Jamajigi & 29 & 28 & 19 & 9 & 23 & 16 & 3 & 10 & V. Verdier \\
\hline MAI7 (CFBP7334) & Niono, Mali & 2004 & O. sativa var. Jamajigi & 30 & 29 & 17 & 10 & 24 & 16 & 3 & 11 & V. Verdier \\
\hline MAI8 (CFBP7330) & Niono, Mali & 2004 & O. sativa var. Nonioka & 31 & 28 & 17 & 8 & 22 & 17 & 3 & 12 & V. Verdier \\
\hline MAI10 (CFBP7331) & Niono, Mali & 2004 & O. sativa var. Nonioka & 27 & 30 & 17 & 8 & 22 & 17 & 3 & 12 & V. Verdier \\
\hline MAI11 (CFBP7335) & Niono, Mali & 2004 & O. sativa var. Jamajigi & 27 & 30 & 18 & 8 & 21 & 18 & 3 & 13 & V. Verdier \\
\hline \multicolumn{13}{|l|}{ Stability panel } \\
\hline FJ11 & Fujian, China & 2008 & O. sativa var. Yongyou 6 & $\ldots$ & $\ldots$ & $\ldots$ & $\ldots$ & $\ldots$ & $\ldots$ & $\ldots$ & 14 & J. X. Feng \\
\hline FJ12 & Fujian, China & 2008 & O. sativa var. Yongyou 6 & $\ldots$ & $\ldots$ & $\ldots$ & $\ldots$ & $\ldots$ & $\ldots$ & $\ldots$ & 15 & J. X. Feng \\
\hline FJ13 & Fujian, China & 2008 & O. sativa var. Yongyou 6 & $\ldots$ & $\ldots$ & $\ldots$ & $\ldots$ & $\ldots$ & $\ldots$ & $\ldots$ & 16 & J. X. Feng \\
\hline MAI18 (CFBP7338) & Kogoni, Mali & 2009 & O. longistaminata & $\ldots$ & $\ldots$ & $\ldots$ & $\ldots$ & $\ldots$ & $\ldots$ & $\ldots$ & 17 & V. Verdier \\
\hline MAI19 & Kogoni, Mali & 2009 & O. longistaminata & $\ldots$ & $\ldots$ & $\ldots$ & $\ldots$ & $\ldots$ & $\ldots$ & $\ldots$ & 17 & I. Wonni \\
\hline MAI21 & Kogoni, Mali & 2009 & O. longistaminata & $\ldots$ & $\ldots$ & $\ldots$ & $\ldots$ & $\ldots$ & $\ldots$ & $\ldots$ & 18 & 35 \\
\hline
\end{tabular}

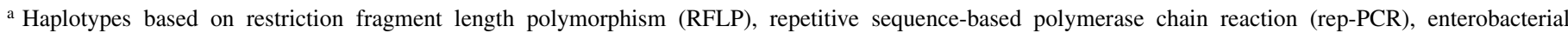
repetitive intergenic consensus (ERIC)-PCR, and amplified fragment length polymorphism (AFLP) analyses were taken from Gonzalez et al. (12). Same numbers indicate the same haplotype. VNTR = variable number of tandem repeats.

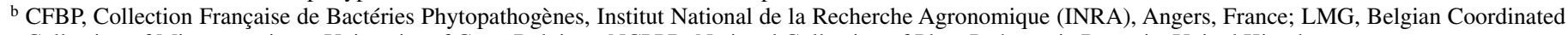
Collection of Microorganisms, University of Gent, Belgium; NCPPB, National Collection of Plant Pathogenic Bacteria, United Kingdom. 
Tools/msa/muscle/) (10). PCR primers matching conserved segments were designed using the Finnzymes website (http://www. finnzymes.fi/tm_determination.html) (Table 2). To allow multiplexing, primers were designed to have similar annealing temperatures at $69.5 \pm 2.5^{\circ} \mathrm{C}$ at $200 \mathrm{nM}$ primer concentration and
$50 \mathrm{mM}$ salt concentration. Designed primer sequences were queried against the $X$. oryzae pv. oryzicola genome sequences using the MFEprimer website (http://biocompute.bmi.ac.cn/MFEprimer/) (25) to confirm that the primer pairs will only amplify one locus per genome.

TABLE 2. Oligonucleotide primers, polymerase chain reaction (PCR) conditions, and characteristics of variable numbers of tandem repeats (VNTR) analyzed in this study

\begin{tabular}{|c|c|c|c|c|c|c|c|c|}
\hline \multirow[b]{3}{*}{ VNTR $^{\mathrm{a}}$} & \multirow[b]{3}{*}{$\mathrm{TRS}^{\mathrm{b}}$} & \multirow[b]{3}{*}{ Position $^{c}$} & \multirow[b]{3}{*}{ Open reading frames ${ }^{\mathrm{d}}$} & \multirow[b]{3}{*}{ Primers $\left(5^{\prime}-3^{\prime}\right)$} & \multicolumn{4}{|c|}{ PCR conditions } \\
\hline & & & & & \multirow[b]{2}{*}{$\mathrm{T}\left({ }^{\circ} \mathrm{C}\right)^{\mathrm{e}}$} & \multicolumn{3}{|c|}{ Amplicon (bp) (number of repeats) ${ }^{\mathrm{f}}$} \\
\hline & & & & & & BLS256 & GX01 & MAI10 \\
\hline B01 & TTCCCAA & 208464-208544 & XOC_0222: SEC-C motif protein & GCACAGCAGCCACGGCAA/ & 55 & $366(11)$ & 338 & $352(12)$ \\
\hline \multirow[t]{2}{*}{ B02 } & CGCACAG & $351012-351077$ & NO & AGGCGGCGTTGCATCGTG/ & & & & \\
\hline & & & & AACAGCGGCGTGCCGATG & 55 & $502(9)$ & $467(4)$ & 467 (4) \\
\hline \multirow[t]{2}{*}{ B03 } & TCCCTCGAA & $446122-446194$ & NO & GGCTCGTCGCTACGGAGC/ & & & & \\
\hline & & & & TGGAACACGGCTGCGTCG & 60 & $405(8)$ & $\mathrm{NC}$ & $\mathrm{NC}$ \\
\hline \multirow[t]{2}{*}{ B04 } & CGATTGCC & $825999-826047$ & XOC_0825: two-component system sensor protein & & & & & \\
\hline & & & $\mathrm{KdpD}$ & $\begin{array}{l}\text { CGTCGGCCGCCAAGTACG/ } \\
\text { GTCTCGGACACGCGCACG }\end{array}$ & 60 & $949(6)$ & $941(5)$ & $946(6)$ \\
\hline \multirow[t]{2}{*}{ B05 } & CGATAC & $1450149-1450186$ & XOC_1467: conserved hypothetical protein & GCAGACGGATGGGCGTTG/ & & & & \\
\hline & & & & CGCTGTCGGCAGGGTTTG & 55 & $343(6)$ & $361(9)$ & $369(7)$ \\
\hline \multirow[t]{2}{*}{ B06 } & AATCGGG & $1453245-1453400$ & XOC_1471: acetyltransferase & GGAATGCCGAAGCGCTCG/ & & & & \\
\hline & & & & TGCTCGACCTGGAAGGCG & 50 & $916(21)$ & $881(16)$ & $790(3)$ \\
\hline \multirow[t]{2}{*}{ B07 } & GGCAGT & $1523859-1523924$ & XOC_1550: conserved hypothetical protein & TAATCGGCACCGGCGAGC/ & & & & \\
\hline & & & & AAGGCGATGCTGCTGGGC & 55 & $623(10)$ & $631(6)$ & $581(3)$ \\
\hline \multirow{2}{*}{ B08 } & TGAGCCT & $1666816-1666862$ & XOC_1684: hypothetical protein & GCGGTGGGCAGCGATGTC/ & & & & \\
\hline & & & & ATGGTTGTGGTGCGGCGG & 50 & $705(6)$ & $729(5)$ & $698(5)$ \\
\hline B09 & CGGGAAT & $1775575-1775625$ & NO & CGCGCCGATCACGCCTTG/ & & & & \\
\hline & & & & GGCCACAAACGCAACCCG & 55 & $511(7)$ & $497(5)$ & $497(5)$ \\
\hline $\mathrm{B} 10$ & AATCCCG & $1838952-1838993$ & NO & GCGCTACACCGGCTTCGC/ & & & & \\
\hline & & & & ATCGGAACGTGGCTGCGC & 55 & $284(6)$ & $277(5)$ & $277(3)$ \\
\hline B11 & CCTGGA & $2154494-2154537$ & XOC_2159: hypothetical protein & CTGCCGGCCTTGCCCAAG/ & & & & \\
\hline & & & & ATGCTTGCGCGTCCACGG & 55 & $614(7)$ & $590(3)$ & $596(4)$ \\
\hline B12 & CAGGCC & 2159999-2160079 & XOC_2163: N-acetylmuramoyl-L-alanine amidase & TGACCCGCATACGCAGCG/ & & & & \\
\hline & & & & AAGCGGTCATCGCTGCGG & 58 & $448(13)$ & $400(5)$ & $406(6)$ \\
\hline B13 & TGGCAG & $2574214-2574251$ & XOC_2531: FHA domain protein & TGGATCAGCGTGACCGGC/ & & & & \\
\hline & & & & TCGCCACCTCGTTCACGC & 65 & $499(6)$ & $517(11)$ & $526(13)$ \\
\hline B14 & GGCGGAT & 2857319-2857385 & XOC_2789: Smr domain protein & GGATCTGCACGGCGCCAC/ & & & & \\
\hline & & & & CGCCTTGTCCGATCCGCA & 55 & $789(9)$ & $754(4)$ & $789(10)$ \\
\hline B15 & GCAGGT & $3164085-3164120$ & XOC_3096: putative secreted protein & CCGACCAATGCCGAGCAG/ & & & & \\
\hline & & & & CCAGTCTTCGGCCCAGCG & 55 & $168(6)$ & $162(5)$ & $150(3)$ \\
\hline B16 & CGAGATT & $3243409-3243450$ & NO & GCTCGGCCACGAAGCTGC/ & & & & \\
\hline & & & & GCGCATGAAGCAGGTCGG & 55 & $391(6)$ & $384(5)$ & $384(5)$ \\
\hline B17 & CTGCTG & $3605916-3606009$ & NO & AGGCAGGCGAAATCGGCG & & & & \\
\hline & & & & ACGCCGAGGAAGCCGGTG & 60 & $826(15)$ & $937(34)$ & $856(25)$ \\
\hline B18 & CCGATTC & $3731758-3731807$ & XOC_3625: proton glutamate symport protein & ACGGATGGCGTTGGCCAG & & & & \\
\hline & & & & TCGGCATGATCCTGGGCG & 55 & $395(7)$ & $367(3)$ & $374(4)$ \\
\hline B19 & TGCTGTTGC & 3919919-3919977 & XOC_3795: general secretion pathway protein $\mathrm{N}$ & GAAACAGGCGCGGCGTCA & & & & \\
\hline & & & & CTGACCGGCGTGCTGCTG & 55 & $576(6)$ & $609(10)$ & $600(10)$ \\
\hline B20 & TGGCTAT & $3942348-3942533$ & XOC_3810: conserved hypothetical protein & GCTTGGCGGGTCACATCG & & & & \\
\hline & & & & TGGATCGACGCCGGACTG & 55 & $483(26)$ & $364(9)$ & $406(17)$ \\
\hline B21 & TGATTGGC & $4317966-4318022$ & XOC_4162: hypothetical protein & ACCCGGCAACTCGCAACC & & & & \\
\hline & & & & GGCACGAGCAAGCGGCAT & 55 & $318(7)$ & $358(12)$ & $366(13)$ \\
\hline G01 & GGCGGT & $797716-797740$ & NO & TCAAGCGCGTCGCATTGC & & & & \\
\hline & & & & CAAGACACGCCGGCATGC & 67 & $626(4)$ & $674(12)$ & $620(3)$ \\
\hline G04 & TCTCT & $1812443-1812462$ & NO & ACAGGCATCGGCCGATTC & & & & \\
\hline & & & & GGGGTCTGCTGGGTCGAC & 55 & $272(4)$ & $282(6)$ & $277(5)$ \\
\hline G05 & CGCGTG & $1796631-1796682$ & XOC_1822: ABC transporter ATP-binding protein & CAGCACAGCGATCGCCTG & & & & \\
\hline & & & & CAGGGGCTGCGCAGCTAC & 53 & $367(8)$ & $361(7)$ & $355(6)$ \\
\hline G09 & CGGCAA & $712624-712868$ & XOC_0712: rod shape-determining protein & GGACACCATGCCCGTCGG & & & & \\
\hline & & & & GGACACCATGCCCGTCGG & 65 & $339(5)$ & $386(6)$ & $386(8)$ \\
\hline G11 & CCGCGT & $2578487-2578508$ & XOC_2535: transposase & AGCCCCACCCAATCACGC & & & & \\
\hline & & & & ACGCGGAGCAAAAGGCGT & 55 & $401(3)$ & $416(6)$ & $328(3)$ \\
\hline M01 & TCGGGAT & 2792163-2792193 & NO & CGCAGATGCTCGTTGCCG & & & & \\
\hline & & & & CGATGCGACGCTGGATGC & 60 & $554(4)$ & $561(5)$ & $568(6)$ \\
\hline M08 & GGGATTC & $3518302-3518341$ & NO & CAGGGCGAACGCGATGAG & & & & \\
\hline & & & & GCTCCATGGTGCCGGAGA & 58 & $427(5)$ & 427 (5) & $441(7)$ \\
\hline
\end{tabular}

a VNTR loci.

b Tandem repeat sequence.

c Position in strain BLS256.

d Annotated function in strain BLS256.

e Annealing temperature.

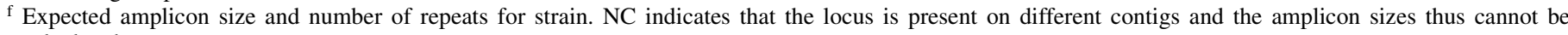
calculated. 
PCR amplification, agarose gel electrophoresis, and DNA sequencing. PCR amplifications were performed using genomic DNA of $X$. oryzae pv. oryzicola strains, including the reference strains BLS256, MAI10, and GX01 as the template. Each PCR reaction was carried out in a final volume of $25 \mu \mathrm{l}$ and containing 5 to $10 \mathrm{ng}$ of genomic DNA, $2.5 \mathrm{mM} \mathrm{MgCl}_{2}, 40 \mathrm{nM}$ PCR primers, $2 \mathrm{mM} \mathrm{dNTP}$, and 0.5 units of Taq DNA polymerase (Promega Corp., Madison, WI) in $1 \times$ buffer. All reactions were run for 35 cycles, each consisting of $30 \mathrm{~s}$ at $94^{\circ} \mathrm{C}, 30 \mathrm{~s}$ at 50 to $67^{\circ} \mathrm{C}$ (depending on the primer pair), and $60 \mathrm{~s}$ at $72^{\circ} \mathrm{C}$, with an initial activation step of $5 \mathrm{~min}$ at $94^{\circ} \mathrm{C}$ and a final extension step of $10 \mathrm{~min}$ at $72^{\circ} \mathrm{C}$.

PCR products were separated on $1.2 \%$ agarose gels and visualized under UV upon staining with ethidium bromide. PCRamplified VNTR loci from the panel of 20 X. oryzae pv. oryzicola strains were adjusted to the required DNA concentration (at least $30 \mathrm{ng} / \mu \mathrm{l}$ ) and sent for custom DNA sequencing (Beckman Coulter Genomics, UK).

Description and analysis of VNTR profiles. The number of repeats of each VNTR allele was counted upon alignment of DNA sequences using the MUSCLE software. Repeat numbers were rounded to the closest integer number. The allelic profile of a given strain was defined as the repeat numbers at each VNTR locus included in the MLVA scheme. The discriminatory power of single and combined (MLVA-25) VNTR loci, MLSA, RFLP, and rep-PCR data were calculated using the Hunter-Gaston discriminatory index (HGDI), using the following formula:

$$
D=1-\left[\frac{1}{N(N-1)} \sum_{j=1}^{S} x j(x j-1)\right]
$$

where $D$ is the numerical index of discriminatory power, $N$ is the total number of strains in the typing scheme, $s$ is the total number of different strain types, and $x j$ is the number of strains belonging to the $j$ th type (14).
Phylogenetic trees were derived from repeat numbers, based on neighbor joining using the continuous Manhattan dissimilarity index of the software package DARwin, version 5.0.158, from CIRAD France (http://darwin.cirad.fr/) (22).

\section{RESULTS}

Exploitation of genomic resources for development of an MLVA scheme for $\boldsymbol{X}$. oryzae pv. oryzicola. Complete and draft $X$. oryzae pv. oryzicola genome sequences were used to predict VNTR loci with at least six tandem repeats of 5 to $9 \mathrm{bp}$ in length. For the completely sequenced Philippine strain BLS256, 21 loci were predicted, whereas, for the two draft genome sequences of strains GX01 and MAI10, only 11 and 10 loci were predicted, respectively (Fig. 1; Table 2). Nine loci from BLS256 were also predicted for GX01 (B06), for MAI10 (B12, B14, and B19), or for both of these strains (B01, B05, B13, B17, and B20). Based on the conservation of flanking regions, all 42 predicted loci could be grouped to 28 distinct VNTR loci (Fig. 1A). BLAST analyses revealed that all predicted loci were also present in the other strains, even if they were not predicted due to smaller number of repeats or higher variability among individual repeats than required by our prediction parameters. All predicted loci were mapped onto the genome sequence of strain BLS256 and were found to be randomly distributed along the chromosome (Fig. 1B).

Multiple sequence alignment of flanking regions allowed design of universal PCR primers for Asian and African strains of $X$. oryzae pv. oryzicola (Table 2). In silico PCR predicted that the amplified DNA fragments of all 28 loci should be polymorphic among the three sequenced strains of $X$. oryzae pv. oryzicola (Table 2).

VNTR analyses of a test panel of $X$. oryzae pv. oryzicola strains. To assess the utility of the 28 candidate VNTR loci for
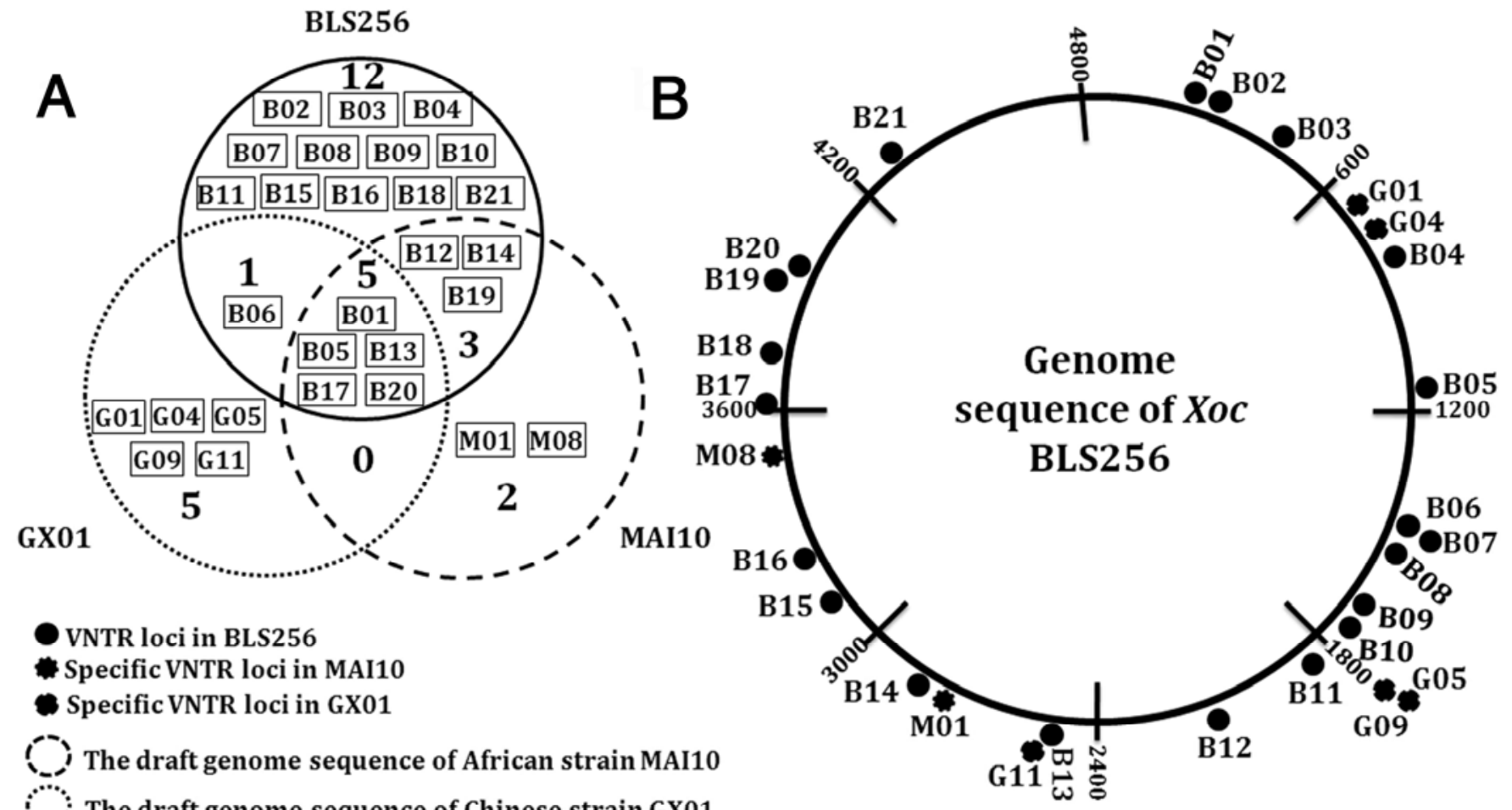

VNTR loci in BLS256

- Specific VNTR loci in MAI10

Specific VNTR loci in GX01

The draft genome sequence of African strain MAI10

The draft genome sequence of Chinese strain GX01

The complete genome sequence of Philippine strain BLS256

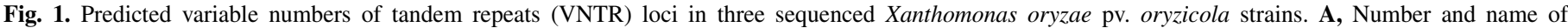

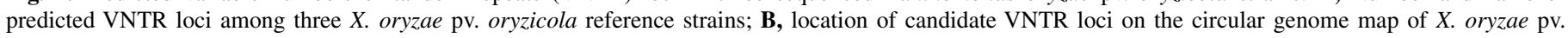
oryzicola strain BLS256. 
the development of an MLVA typing scheme, we selected 20 strains from our collection as a test panel (Table 1). Fourteen strains representing worldwide diversity, including seven Asian isolates (three strains from China, three strains from Malaysia, and the Philippine reference strain BLS256) and seven African strains (all from Mali), served as a diversity panel. Twice, three supposedly closely related strains originating from China and Mali were included in the study to elucidate the resolution of the VNTR loci (Table 1, stability panel). These strains had been collected in the same year, in the same region, and from the same cultivar.

Upon PCR amplification and confirmation by analytical agarose gel electrophoresis, DNA fragments were sequenced using one of the PCR primers, thus allowing an estimate of the number of tandem repeats for every VNTR locus (Table 3 ). Among the 28 candidate VNTR loci, 25 yielded amplification products for most $X$. oryzae pv. oryzicola strains and allowed unambiguous assignment of the number of tandem repeats. However, three loci (B07, B12, and G01) provided unsatisfactory results (Table 3). For B07 and B12 loci, sequences from nearly half of the strains were entirely different from those of the reference strains. For G01, only poor amplification was observed for several strains, suggesting that this locus is not widespread in $X$. oryzae pv. oryzicola strains from Asia (UBP497) and Africa.

For the remaining 25 unambiguous VNTR loci, repeat numbers were polymorphic among the set of 20 strains. Altogether, 18 unique VNTR patterns (haplotypes) were resolved (Table 4). Repeat numbers varied between 2 (B06 and B08) and >40 (B17 and B20). On average, 5.6 haplotypes were observed per locus. Some loci had only two to three haplotypes (B10, B16, G11, and M01) and appeared to be stable. In contrast, other loci consisting of high repeat numbers appeared to evolve rapidly, thus resulting in up to 13 haplotypes (B06, B17, B20, and B21).

For some loci (B06 in strain BLS256; B06, B07, and B17 in strain GX01; and B01, B10, B14, B17, B20, and G19 in strain MAI10), discrepancies were observed between our experimentally derived amplicon sizes and the sizes predicted from the available genome sequences (Table 5). For instance, B06 was predicted to be $923 \mathrm{bp}$ in BLS256, whereas it was observed to be $916 \mathrm{bp}$, corresponding to a difference of a single 7-bp repeat unit. Likewise, B06 was predicted to be 1,413 bp in GX01, whereas it was observed to be $881 \mathrm{bp}$, corresponding to a difference of 76 7-bp repeat units; and B17 was predicted to be 856 bp in MAI10,

TABLE 4. Hunter-Gaston discriminatory index (HGDI) scores for individual or combined (MLVA-25) variable numbers of tandem repeats (VNTR) loci calculated for 20 Xanthomonas oryzae pv. oryzicola strains

\begin{tabular}{lccc}
\hline VNTR loci & Range of repeat number $^{\mathrm{a}}$ & Haplotypes & HGDI scores \\
\hline B01 & $7-14$ & 7 & 0.795 \\
B02 & $3-9$ & 7 & 0.779 \\
B03 & $3-8$ & 5 & 0.653 \\
B04 & $5-8$ & 4 & 0.658 \\
B05 & $5-9$ & 5 & 0.721 \\
B06 & $2-32$ & 9 & 0.795 \\
B07 & Unrelated & & \\
B08 & $2-6$ & 5 & 0.695 \\
B09 & $4-7$ & 4 & 0.363 \\
B10 & $3-6$ & 3 & 0.511 \\
B11 & $3-8$ & 6 & 0.737 \\
B12 & Unrelated & & \\
B13 & $5-10$ & 5 & 0.706 \\
B14 & $3-11$ & 7 & 0.847 \\
B15 & $3-6$ & 4 & 0.623 \\
B16 & $5-6$ & 2 & 0.526 \\
B17 & $13-47$ & 8 & 0.795 \\
B18 & $3-11$ & 6 & 0.737 \\
B19 & $3-14$ & 7 & 0.795 \\
B20 & $6-49$ & 13 & 0.953 \\
B21 & $5-17$ & 9 & 0.858 \\
G01 & Poor & & \\
G04 & $3-6$ & 4 & 0.647 \\
G05 & $4-9$ & 5 & 0.712 \\
G09 & $4-10$ & 5 & 0.816 \\
G11 & $3-6$ & 3 & 0.484 \\
M01 & $4-6$ & 3 & 0.700 \\
M08 & $5-10$ & 5 & 0.726 \\
MLVA-25 & $2-49$ & 18 & 0.974 \\
\hline U1 & & &
\end{tabular}

${ }^{\mathrm{a}}$ Unrelated $=$ unrelated loci and poor $=$ poorly conserved.

TABLE 3. Repeat numbers of 28 variable numbers of tandem repeats (VNTR) loci in 20 Xanthomonas oryzae pv. oryzicola strains

\begin{tabular}{|c|c|c|c|c|c|c|c|c|c|c|c|c|c|c|c|c|c|c|c|c|c|c|c|c|c|c|c|c|c|}
\hline Loci $^{\mathrm{a}}$ & Country & B01 & B02 & B03 & B04 & B05 & B06 & B07 & B08 & B09 & B10 & B11 & $\mathrm{B} 12$ & B13 & B14 & B15 & B16 & B17 & B18 & B19 & B20 & B21 & G01 & G04 & G05 & G09 & G11 & M01 & M08 \\
\hline Minimum & & 7 & 3 & 3 & 5 & 5 & 2 & 4 & 2 & 4 & 3 & 3 & 3 & 5 & 3 & 3 & 5 & 13 & 3 & 3 & 6 & 5 & 3 & 3 & 4 & 4 & 3 & 4 & 5 \\
\hline Maximum & & 14 & 9 & 8 & 8 & 9 & 32 & 10 & 6 & 7 & 6 & 8 & 13 & 10 & 11 & 6 & 6 & 47 & 11 & 14 & 49 & 17 & 12 & 6 & 9 & 10 & 6 & 6 & 10 \\
\hline Haplotype & & 7 & 7 & 5 & 4 & 5 & 9 & 6 & 5 & 4 & 3 & 6 & 6 & 5 & 7 & 4 & 2 & 8 & 6 & 7 & 13 & 9 & 5 & 4 & 5 & 5 & 3 & 3 & 5 \\
\hline \multicolumn{30}{|l|}{ I } \\
\hline FJ13 & Fujian, China & 13 & 8 & 5 & 8 & 5 & 14 & 9 & 3 & 5 & 5 & 3 & 8 & 7 & 9 & 4 & 6 & 13 & 5 & 5 & 33 & 16 & 3 & 4 & 4 & 4 & 4 & 4 & 8 \\
\hline FJ12 & Fujian, China & 12 & 7 & 5 & 7 & 6 & 19 & 6 & 3 & 5 & 5 & 3 & 6 & 7 & 9 & 5 & 6 & 13 & 5 & 5 & 36 & 17 & 3 & 4 & 4 & 4 & 4 & 4 & 8 \\
\hline GX07 & Guangxi, China & 13 & 7 & 5 & 7 & 6 & 15 & 8 & 3 & 5 & 5 & 3 & 7 & 7 & 10 & 5 & 6 & 13 & 5 & 5 & 33 & 14 & 3 & 4 & 4 & 5 & 4 & 4 & 8 \\
\hline FJ15 & Fujian, China & 14 & 9 & 5 & 8 & 6 & 15 & 8 & 3 & 5 & 5 & 3 & 7 & 7 & 4 & 5 & 6 & 13 & 5 & 5 & 28 & 16 & 3 & 4 & 4 & 4 & 4 & 4 & 8 \\
\hline CFBP2287 & Malaysia & 11 & 6 & 5 & 6 & 7 & 11 & - & 3 & 4 & 3 & 3 & - & - & 8 & 5 & 6 & 13 & 6 & 3 & 49 & 9 & 7 & 4 & 4 & 5 & 3 & 4 & 8 \\
\hline CFBP2286 & Malaysia & 12 & 7 & 6 & 7 & 6 & 21 & - & 5 & 6 & 3 & 6 & - & 6 & 11 & 6 & 6 & 20 & 11 & 5 & 24 & 5 & 5 & 4 & - & 5 & 3 & 4 & 5 \\
\hline BLS256 & Philippine & 11 & 9 & 8 & 6 & 6 & 21 & 10 & 6 & 7 & 6 & 7 & 13 & 6 & 9 & 6 & 6 & 15 & 7 & 6 & 26 & 7 & 4 & 4 & 8 & 5 & 3 & 4 & 5 \\
\hline \multicolumn{30}{|l|}{ II } \\
\hline FJ11 & Fujian, China & 9 & 4 & 3 & 5 & 7 & 32 & 8 & 4 & 5 & 5 & 3 & 5 & 10 & 5 & 5 & 5 & 47 & 3 & 9 & 24 & 12 & 4 & 6 & 7 & 6 & 6 & 5 & 5 \\
\hline GX01 & Guangxi, China & 7 & 4 & 3 & 5 & 9 & 16 & 6 & 5 & 5 & 5 & 3 & 5 & 9 & 4 & 5 & 5 & 34 & 3 & 10 & 9 & 12 & 12 & 6 & 7 & 6 & 6 & 5 & 5 \\
\hline MAI3 & Niono, Mali & 8 & 3 & 4 & 5 & 5 & 11 & - & 5 & 5 & 3 & 3 & - & 5 & 8 & 3 & 5 & 28 & 4 & 14 & 11 & 11 & 4 & 5 & 9 & 5 & 3 & 5 & 6 \\
\hline \multicolumn{30}{|l|}{ III } \\
\hline MAI10 & Niono, Mali & 12 & 4 & 3 & 6 & 7 & 3 & - & 5 & 5 & 3 & 4 & 6 & 7 & 10 & 3 & 5 & 25 & 4 & 10 & 17 & 13 & - & 5 & 6 & 8 & 3 & 6 & 7 \\
\hline MAI8 & Niono, Mali & 12 & 4 & 3 & 6 & 7 & 3 & - & 5 & 5 & 3 & 4 & - & 7 & 10 & 3 & 5 & 25 & 4 & 10 & 17 & 13 & - & 5 & 6 & 8 & 3 & 6 & 7 \\
\hline MAI4 & Niono, Mali & 12 & 4 & 3 & 6 & 7 & 3 & - & 5 & 5 & 3 & 4 & - & 7 & 10 & 3 & 5 & 20 & 4 & 10 & 17 & 13 & 3 & 5 & 6 & 8 & 3 & 6 & 7 \\
\hline MAI21 & Niono, Mali & 12 & 4 & 3 & 6 & 7 & 3 & - & 5 & 5 & 3 & 4 & - & 6 & 11 & 3 & 5 & 20 & 4 & 10 & 10 & 12 & 3 & 5 & 6 & 8 & 3 & 6 & 7 \\
\hline MAI5 & Niono, Mali & 12 & 4 & 3 & 6 & 7 & 3 & - & 5 & 5 & 3 & 4 & - & 7 & 11 & 3 & 5 & 20 & 4 & 10 & 10 & 12 & 3 & 5 & 6 & 8 & 3 & 6 & 7 \\
\hline MAI11 & Niono, Mali & 11 & 4 & 3 & 6 & 7 & 3 & - & 5 & 5 & 3 & 4 & 6 & 7 & 11 & 3 & 5 & 20 & 4 & 10 & 15 & 12 & - & 5 & - & 8 & 3 & 6 & 7 \\
\hline MAI19 & Niono, Mali & 7 & 5 & 3 & 6 & 8 & 3 & - & 4 & 5 & 3 & 5 & - & 5 & 9 & 3 & 6 & 20 & 4 & 9 & 14 & 12 & 4 & 5 & 6 & 10 & 3 & 5 & 7 \\
\hline MAI18 & Niono, Mali & 7 & 5 & 3 & 6 & 8 & 3 & - & 4 & 5 & 3 & 5 & - & 5 & 9 & 3 & 6 & 20 & - & 9 & 14 & 12 & - & 5 & 6 & 10 & 3 & 5 & 7 \\
\hline MAI7 & Niono, Mali & 12 & 4 & 3 & 6 & 6 & 3 & - & 5 & 5 & 3 & 4 & 4 & - & 9 & 3 & 6 & 31 & 4 & 7 & 10 & 14 & - & 5 & 6 & 6 & 3 & 5 & 7 \\
\hline \multicolumn{30}{|l|}{ IV } \\
\hline UBP497 & Malaysia & - & 3 & 6 & 7 & 7 & 2 & - & 2 & 6 & 3 & 8 & 3 & 5 & 3 & 3 & - & 20 & 3 & 5 & 6 & 11 & - & 3 & 4 & 4 & 3 & 5 & 10 \\
\hline
\end{tabular}

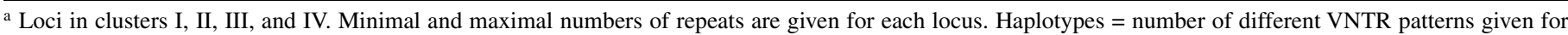
each locus; - indicates that polymerase chain reaction (PCR) amplification failed or DNA sequence of the PCR amplicon was not related to the VNTR locus. 
whereas it was observed to be $886 \mathrm{bp}$, corresponding to a difference of five 6-bp repeat units.

Discriminatory indices (HGDI) were calculated for all VNTR loci except for B07, B12, and G01 (Table 4). HGDI scores varied significantly from 0.363 for B09 to 0.953 for B20. As described previously (28), VNTR loci were classified into highly $(>0.6)$, moderately $(0.3$ to 0.6$)$, and poorly $(<0.3)$ discriminating based on the HGDI scores. Of the 25 loci, 22 loci showed high discriminatory power. Only three loci (B09, B10, and G11) were found to be only moderately discriminatory $(0.336,0.511$, and 0.484, respectively) (Table 4). Combining all 25 VNTR loci into an MLVA-25 scheme resulted in an HGDI score of 0.974, thus demonstrating their suitability for typing of $X$. oryzae pv. oryzicola strains.

New diagnostic markers specific to strains from China and Mali. Some haplotypes were clearly distinct when comparing Asian strains with African strains. Except for strain MAI3, which shares several features with Asian strains and might have been introduced to Africa recently (13), 11 loci were not polymorphic among the African $X$. oryzae pv. oryzicola strains (Table 3). Locus B06 contains only three repeats in strains from Mali (except for MAI3), while most Asian strains have repeat arrays with $>10$ copies. Locus B20 is another striking example where most Asian strains exhibit a higher number of repeat units (24 to 49, except for strains UBP497 and GX01) than the African strains (10 to 17 ) (Table 3 ; Fig. 2).

In senso stricto, not taking into account a possible Asian origin of strain MAI3, 19 of 25 VNTR loci were polymorphic in Malian strains (except for B09, B10, B15, B18, G04, and G11) while 22 of 25 were polymorphic in Chinese strains from Guangxi and Fujian provinces (except for B09, B10, and B11). Therefore, one could consider the nonpolymorphic loci as diagnostic markers for strains from China and Mali. Specifically, a VNTR profile with five, five, and three repeats for B09, B10, and B11, respectively (called VNTR-C profile of 5-5-3) might serve as a marker for Chinese strains. Likewise, a VNTR-M profile of 5-3-3-4-5-3 for B09, B10, B15, B18, G04, and G11 would indicate an origin from Mali.

Phylogenetic analysis. To study the genetic relationships among Asian and African $X$. oryzae pv. oryzicola strains, an unweighted pair group with arithmetic means cluster analysis based on Manhattan genetic distances was performed (Fig. 2). In

TABLE 5. Comparison of observed and expected sizes of variable numbers of tandem repeats (VNTR) markers in Xanthomonas oryzae pv. oryzicola reference strains $^{\mathrm{a}}$

\begin{tabular}{|c|c|c|c|c|c|c|c|c|c|c|c|c|}
\hline \multirow[b]{3}{*}{ VNTR marker } & \multicolumn{4}{|c|}{ BLS256 } & \multicolumn{4}{|c|}{ GX01 } & \multicolumn{4}{|c|}{ MAI10 } \\
\hline & \multicolumn{2}{|c|}{ Expected } & \multicolumn{2}{|c|}{ Observed } & \multicolumn{2}{|c|}{ Expected } & \multicolumn{2}{|c|}{ Observed } & \multicolumn{2}{|c|}{ Expected } & \multicolumn{2}{|c|}{ Observed } \\
\hline & Size (bp) & $\mathrm{RN}$ & Size (bp) & $\mathrm{RN}$ & Size (bp) & $\mathrm{RN}$ & Size (bp) & $\mathrm{RN}$ & Size (bp) & $\mathrm{RN}$ & Size (bp) & RN \\
\hline B07 & $\ldots$ & $\ldots$ & $\ldots$ & $\ldots$ & 625 & 5 & 631 & 6 & $\ldots$ & $\ldots$ & $\ldots$ & $\ldots$ \\
\hline B17 & $\ldots$ & $\ldots$ & $\ldots$ & $\ldots$ & 889 & 26 & 937 & 34 & 856 & 20 & 886 & 25 \\
\hline B01 & $\ldots$ & $\ldots$ & $\ldots$ & $\ldots$ & $\ldots$ & $\ldots$ & $\ldots$ & $\ldots$ & 352 & 9 & 373 & 12 \\
\hline B10 & $\ldots$ & $\ldots$ & $\ldots$ & $\ldots$ & $\ldots$ & $\ldots$ & $\ldots$ & $\ldots$ & 277 & 5 & 263 & 3 \\
\hline B20 & $\ldots$ & $\ldots$ & $\ldots$ & $\ldots$ & $\ldots$ & $\ldots$ & $\ldots$ & $\ldots$ & 406 & 15 & 420 & 17 \\
\hline
\end{tabular}

${ }^{\text {a }}$ Size $=$ amplicon size and $\mathrm{RN}=$ repeat number.

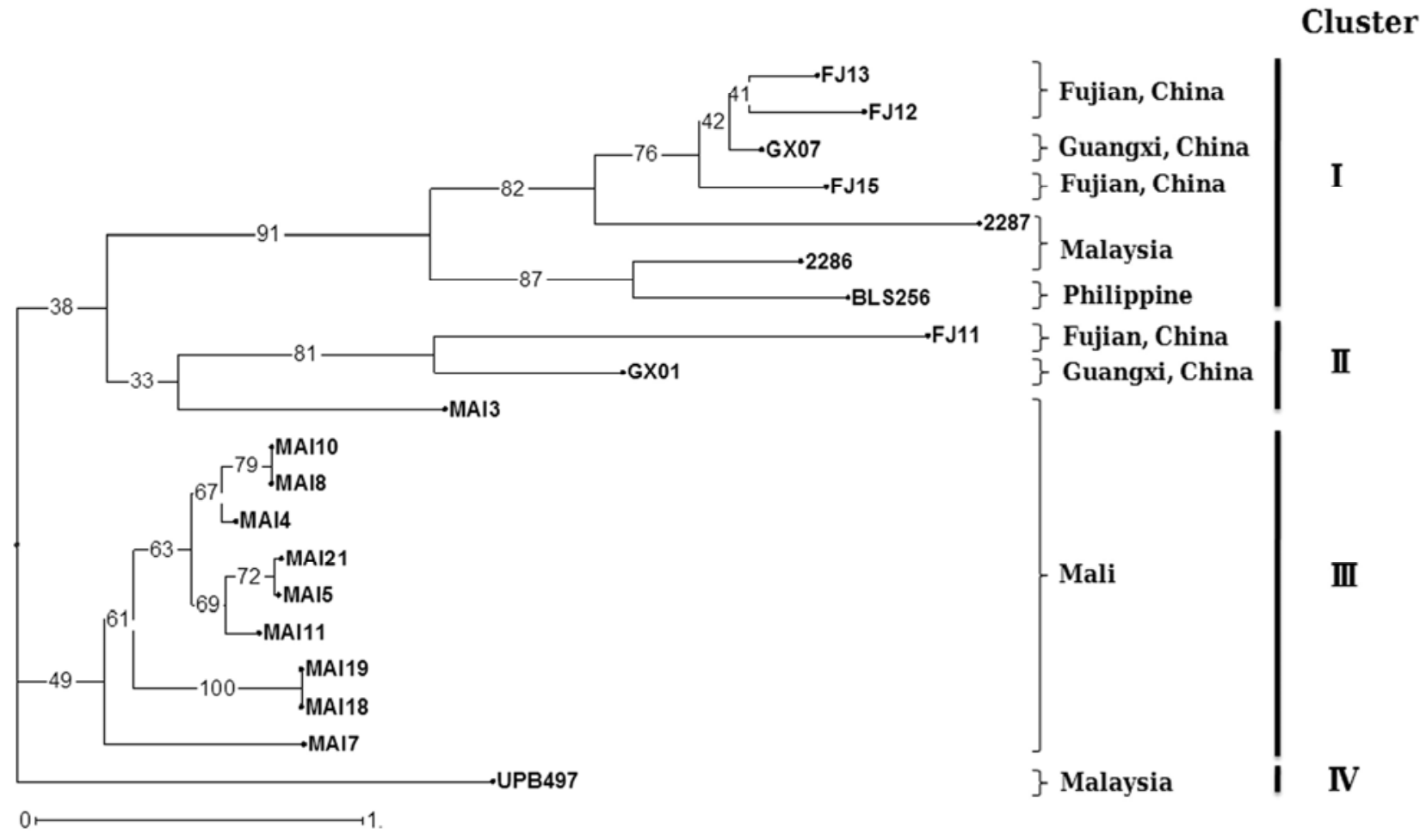

Fig. 2. Dendrogram of 20 Xanthomonas oryzae pv. oryzicola strains obtained by neighbor joining using the continuous Manhattan dissimilarity index. Bootstrap values (for 1,000 replicates) are given at the nodes. 
the resulting dendrogram, Asian strains were clearly separated from African strains, except for MAI3. All X. oryzae pv. oryzicola strains were grouped into four clusters which widely reflected their geographic origin. Cluster I was composed of Asian strains, including four Chinese strains (GX07, FJ12, FJ13, and FJ15), two Malaysian strains (CFBP2286 and CFBP2287), and the Philippine strain BLS256. Cluster III exclusively consisted of strains from Mali. Strikingly, cluster II contains two Chinese strains and one African stain, MAI3, further supporting a possible Asian origin of strain MAI3. One Malaysian strain, UPB497, was clearly separated from all other strains and made up cluster IV.

\section{DISCUSSION}

MLVA has become an important and popular typing tool to study the population structure of many human and animal pathogens because this technique is highly discriminatory, portable, robust, and fast $(23,32,34)$. Although the first VNTR study of a bacterial plant pathogen, $X$. fastidiosa, dates back to 2001 (9), VNTR has not yet received much attention in the field of bacterial phytopathology, probably owing to limited access to (multiple) genome sequences. Only recently, VNTR analyses were used to characterize other plant pathogens, such as 'Candidatus Liberibacter spp.', Pseudomonas syringae, and X. citri $(5,11,16,24)$. Here, we took advantage of the availability of three genome sequences of $X$. oryzae pv. oryzicola to develop the first MLVA typing scheme for rice-pathogenic xanthomonads.

Most PCR primers allowed unambiguous amplification of only one specific VNTR-related DNA fragment, demonstrating that the method is robust and useful for large-scale analyses. In a few cases, however, amplification failed despite several attempts (B01 and B16 for strain UBP497; G05 for CFBP2286 and MAI11; B13 for CFBP2287 and MAI7; and B18 for MAI18). Either these VNTR loci are not present in these strains; they have been disrupted by IS elements, preventing amplification due to the large size; or they suffer from mutations at the primer binding sites. With the available sequence information generated within this project, we will evaluate new PCR primers to amplify the few missing loci.

In this study, a few discrepancies appeared between our experimentally derived amplicon sizes and the sizes predicted from the available genome sequences (Table 5). We assume that these discrepancies are due to mistakes in the genome assemblies,

TABLE 6. Hunter-Gaston discriminatory index (HGDI) scores for combined (MLVA-25) variable numbers of tandem repeats (VNTR) loci, restriction fragment length polymorphism (RFLP), multi-locus sequence analysis (MLSA), and repetitive sequence-based polymerase chain reaction (rep-PCR) profiles calculated for nine Xanthomonas oryzae pv. oryzicola strains from the diversity panel

\begin{tabular}{lccc}
\hline Typing methods & Haplotypes & HGDI scores & References \\
\hline MLVA & & & \\
MLVA-25 & 8 & 0.972 & This study \\
RFLP & & & \\
RFLP-IS1112 & 7 & 0.917 & 12 \\
RFLP-IS1113 & 3 & 0.667 & 12 \\
RFLP-avrXa10 & 6 & 0.889 & 12 \\
RFLP-Xoo1762 & 5 & 0.806 & 12 \\
RFLP & 9 & 1 & 12 \\
rep-PCR & & & 12 \\
rep-PCR & 6 & 0.889 & 13 \\
ERIC-PCR & 5 & 0.861 & 13 \\
MLSA & & & 13 \\
gyrB & 3 & 0.644 & 13 \\
rpoD & 1 & 0 & 13 \\
efP & 2 & 0.2 & \\
glnA & 2 & 0.694 & \\
MLSA-4 & 4 & & \\
\hline
\end{tabular}

a $\mathrm{ERIC}=$ enterobacterial repetitive intergenic consensus. especially in the cases of next-generation draft genome sequencing of strains MAI10 (454 technology) and GX01 (Illumina technology). However, we cannot rule out that VNTR loci evolved new repeat numbers during strain propagation, a scenario which might have occurred for strain BLS256; in this case, we only found one difference by one single repeat.

Compared with the previously described typing methods such as rep-PCR, ERIC-PCR, RFLP, and AFLP, our data suggest that MLVA is at least equally powerful to discriminate $X$. oryzae pv. oryzicola strains. For instance, nine strains from the diversity panel (CFBP2286, CFBP2287, MAI3, MAI4, MAI5, MAI7, MAI8, MAI10, and MAI11), originating from Mali and Malaysia, were clearly resolved into eight haplotypes by VNTR markers (HGDI = 0.972), whereas only six and five haplotypes were obtained by rep-PCR (HGDI = 0.889) and ERIC-PCR analysis $($ HGDI $=0.861)$, respectively (Table 6) $(12)$. RFLP analysis with insertion sequence elements (IS1112 and IS1113) or type III effector genes (avrXa10 and Xoo1762) resulted in seven, three, seven, and five haplotypes, respectively, with HGDI scores of 0.667 to 0.917 . Only combination of all four RFLP probes allowed resolution of all nine strains (Table 6) (12). On the other hand, our MLVA scheme did not allow resolution of strains MAI8 and MAI10 that had distinct profiles in two RFLP schemes (IS1112 and avrXa10) (Table 6) (12). Yet, compared with RFLP, VNTR has the advantage of higher sensitivity and better reproducibility. Its high resolution is also supported by the fact that all three Chinese strains and two of the Malian strains from the stability panel had distinct haplotypes, thus demonstrating its suitability for $X$. oryzae pv. oryzicola population typing (Table 1).

Another approach (MLSA) to type X. oryzae pv. oryzicola strains relies on partial sequencing of the four housekeeping genes $r p o D$ (encoding RNA polymerase sigma-70 factor), gyr $B$ (encoding DNA gyrase subunit B), glnA (encoding glutamine synthetase I), and efP (encoding elongation factor P) (13). However, only very few single-nucleotide polymorphisms (SNPs) were found (i.e., zero SNP in $r p o D$, five SNPs in $g y r B$, one SNP in $g \ln A$, and one SNP in efP) among the $X$. oryzae pv. oryzicola strains of the diversity panel (except for the Chinese strains which were not included in that study). Scrutinizing these four genes separately, only one, three, two, and two haplotypes were determined, with HGDI scores of $0,0.644,0.2$, and 0.2 , respectively (13). Combining all four housekeeping genes results in four haplotypes with an HGDI score of 0.694 , far lower than that of our MLVA-25 score (0.972).

Interestingly, DNA sequences of all housekeeping genes are identical between the African strain MAI3 and the Asian strains BLS256, CFBP2286, and UPB497 (originating from the Philippines and Malaysia) (13). In contrast, all other analyzed strains from Mali (MAI4, MAI5, MAI7, MAI8, MAI10, and MAI11) share four SNPs in $g y r B$. We sequenced a gene fragment of $g y r B$ from all six Chinese strains and found them to be identical to the fragments of BLS256, CFBP2286, and UPB497 (data not shown). Hence, these SNPs appear to be diagnostic for Asian and African strains and support the Asian origin of strain MAI3. Finally, the Asian origin of strain MAI3 is further supported by its "Asian" repertoire of type III effectors. In contrast to most African strains, MAI3 does not suffer from an IS element insertion in xop $W$ and this strain contains $x o p A J$ (synonym of avrRxol), a gene which had hitherto only been detected in Asian X. oryzae pv. oryzicola strains but not in other strains of $X$. oryzae $(13,35)$.

Our MLVA-derived dendrogram demonstrated that Asian and African $X$. oryzae pv. oryzicola strains belong to distinct phylogenetic groups (Fig. 2), a finding which was consistent with previous reports $(12,13,35)$. In line with data from MLSA and type III effector mining, Malian strain MAI3 clustered together with two Chinese strains (cluster II), thus supporting an Asian (maybe Chinese) origin of this isolate. Trans-continental transfer of xanthomonads through contaminated germplasm or seed is not 
without precedents and urges the development of sensitive and efficient tools for detection and high-resolution typing $(15,29)$.

Genetic distances among the African strains (except for MAI3) are smaller than those among the Asian strains, even within the set of Chinese strains. One could speculate that African strains are endemic and started to diversify only recently, concomitant with intensification of rice cultivation on the African continent. We included six Chinese strains in our analyses, originating from the two provinces Guangxi and Fujian. Strains of both provinces are found in two different clusters, hinting at a transmission of contaminated rice seed between these two provinces. Notably, strain UBP497 from Malaysia forms an independent cluster, well separated from the other two Malaysian strains. Unfortunately, detailed information about the year and site of collection is not available for all three Malaysian strains. Altogether, this set of VNTR markers will be useful for population analyses at different spatial scales, suggesting that VNTR typing is a novel, powerful technique for epidemiological monitoring of $X$. oryzae $\mathrm{pv}$. oryzicola strains.

Simple diagnostic markers for the discrimination of $X$. oryzae pv. oryzicola strains at large geographic scale could supplement high-resolution molecular typing. Genomic-based diagnostic markers have been developed to distinguish $X$. oryzae pv. oryzae from $X$. oryzae pv. oryzicola strains and to specifically detect U.S. strains related to $X$. oryzae $(17,31)$. However, these markers do not allow researchers to distinguish African from Asian $X$. oryzae pv. oryzicola strains. Although analysis of xopW and xopAJ and detection of specific SNPs in housekeeping genes might allow differentiation of African and Asian X. oryzae pv. oryzicola strains, specific VNTR profiles, such as the VNTR-C profile (repeat numbers of 5-5-3 for B09, B10, and B11, respectively) and the VNTR-M profile (repeat numbers of 5-3-3-4-5-3 for B09, B10, B15, B18, G04, and G11, respectively), would even allow the identification of strains from China and perhaps Mali (Table 4). Analyses of more strains, including isolates from other African and Asian countries, will be necessary to generalize these conclusions. For instance, BLS has been reported also in Madagascar, Nigeria, Senegal, and Burkina Faso (http://www.eppo.int) $(3,36)$ and their analyses will allow researchers to conclude whether or not the Malian strains are representative of African $X$. oryzae pv. oryzicola and whether African and Asian X. oryzae pv. oryzicola strains can be clearly differentiated by our method.

\section{ACKNOWLEDGMENTS}

This work was supported by the French Agence Nationale de la Recherche (ANR-2010-BLAN-1723), the French Direction Générale de l'Armement (2010 34 0006), and the 973 Programme of the Ministry of Science and Technology of China (2012CB114003). S. Zhao is grateful to the Bourses Doctorales en Alternance of the French Embassy in China, the program of postgraduate education and research of Guangxi (T31036), and the plans for joint training doctoral students and academic visiting of postgraduates of Guangxi University (L300278). L. Poulin acknowledges support from the French Direction Générale de l'Armement (2011 60 091). We thank C. Robin Buell and J. Hamilton at Michigan State University for assistance with sequencing of strain MAI10.

\section{LITERATURE CITED}

1. Benson, G. 1999. Tandem repeats finder: A program to analyze DNA sequences. Nucleic Acids Res. 27:573-580.

2. Bogdanove, A. J., Koebnik, R., Lu, H., Furutani, A., Angiuoli, S. V., Patil, P. B., Van Sluys, M. A., Ryan, R. P., Meyer, D. F., Han, S. W., Aparna, G., Rajaram, M., Delcher, A. L., Phillippy, A. M., Puiu, D., Schatz, M. C., Shumway, M., Sommer, D. D., Trapnell, C., Benahmed, F., Dimitrov, G., Madupu, R., Radune, D., Sullivan, S., Jha, G., Ishihara, H., Lee, S. W., Pandey, A., Sharma, V., Sriariyanun, M., Szurek, B., Vera-Cruz, C. M., Dorman, K. S., Ronald, P. C., Verdier, V., Dow, J. M., Sonti, R. V., Tsuge, S., Brendel, V. P., Rabinowicz, P. D., Leach, J. E., White, F. F., and
Salzberg, S. L. 2011. Two new complete genome sequences offer insight into host and tissue specificity of plant pathogenic Xanthomonas spp. J. Bacteriol. 193:5450-5464.

3. Buddenhagen, I. W. 1985. Rice disease evaluation in Madagascar. Int. Rice Comm. Newsl. 34:74-78.

4. Bui Thi Ngoc, L., Vernière, C., Vital, K., Guérin, F., Gagnevin, L., Brisse, S., Ah-You, N., and Pruvost O. 2009. Fourteen minisatellite markers for population studies of the citrus canker bacterium, Xanthomonas citri pv. citri. Mol. Ecol. Res. 9:125-127.

5. Chen, J., Deng, X., Sun, X., Jones, D., Irey, M., and Civerolo, E. 2010. Guangdong and Florida populations of 'Candidatus Liberibacter asiaticus' distinguished by a genomic locus with short tandem repeats. Phytopathology 100:567-572.

6. Coletta-Filho, H. D., Bittleston, L. S., and Almeida, R. P. 2011. Spatial genetic structure of a vector-borne generalist pathogen. Appl. Environ. Microbiol. 77:2596-2601.

7. Coletta-Filho, H. D., and Machado, M. A. 2002. Evaluation of the genetic structure of Xylella fastidiosa populations from different Citrus sinensis varieties. Appl. Environ. Microbiol. 68:3731-3736.

8. Coletta-Filho, H. D., and Machado, M. A. 2003. Geographical genetic structure of Xylella fastidiosa from Citrus in São Paulo State, Brazil. Phytopathology 93:28-34.

9. Coletta-Filho, H. D., Takita, M. A., de Souza, A. A., Aguilar-Vildoso, C. I., and Machado, M. A. 2001. Differentiation of strains of Xylella fastidiosa by a variable number of tandem repeat analysis. Appl. Environ. Microbiol. 67:4091-4095.

10. Edgar, R. C. 2004. MUSCLE: Multiple sequence alignment with high accuracy and high throughput. Nucleic Acids Res. 32:1792-1797.

11. Gironde, S., and Manceau, C. 2012. Housekeeping gene sequencing and multilocus variable-number tandem-repeat analysis to identify subpopulations within Pseudomonas syringae pv. maculicola and Pseudomonas syringae pv. tomato that correlate with host specificity. Appl. Environ. Microbiol. 78:3266-3279.

12. Gonzalez, C., Szurek, B., Manceau, C., Mathieu, T., Sere, Y., and Verdier, V. 2007. Molecular and pathotypic characterization of new Xanthomonas oryzae strains from West Africa. Mol. Plant-Microbe Interact. 20:534546.

13. Hajri, A., Brin, C., Zhao, S., David, P., Feng, J. X., Koebnik, R., Szurek, B., Verdier, V., Boureau, T., and Poussier, S. 2012. Multilocus sequence analysis and type III effector repertoire mining provide new insights into the evolutionary history and virulence of Xanthomonas oryzae. Mol. Plant Pathol. 13:288-302.

14. Hunter, P. R., and Gaston, M. A. 1988. Numerical index of the discriminatory ability of typing systems: An application of Simpson's index of diversity. J. Clin. Microbiol. 26:2465-2466.

15. Jones, J. B., Stall, R. E., and Bouzar, H. 1998. Diversity among xanthomonads pathogenic on 'pepper and tomato. Annu. Rev. Phytopathol. 36:41-58.

16. Katoh, H., Subandiyah, S., Tomimura, K., Okuda, M., Su, H. J., and Iwanami, T. 2011. Differentiation of 'Candidatus Liberibacter asiaticus' isolates by variable-number tandem-repeat analysis. Appl. Environ. Microbiol. 77:1910-1917.

17. Lang, J. M., Hamilton, J. P., Diaz, M. G. Q., Van Sluys, M. A., Burgos, M. R. G., Vera Cruz, C. M., Buell, C. R., Tisserat, N. A., and Leach, J. E. 2010. Genomics-based diagnostic marker development for Xanthomonas oryzae pv. oryzae and X. oryzae pv. oryzicola. Plant Dis. 94:311-319.

18. Li, W., Raoult, D., and Fournier, P. E. 2009. Bacterial strain typing in the genomic era. FEMS Microbiol. Rev. 33:892-916.

19. Lindstedt, B. A. 2005. Multiple-locus variable number tandem repeats analysis for genetic fingerprinting of pathogenic bacteria. Electrophoresis 26:2567-2582.

20. Niño-Liu, D. O., Ronald, P. C., and Bogdanove, A. J. 2006. Xanthomonas oryzae pathovars: Model pathogens of a model crop. Mol. Plant Pathol. 7:303-324.

21. Pan, R. W., Zou, W. C., Xu, D. G., Pan, R. Q., and Ji, C. Y. 2010. Genotypic and pathotypic diversity of the Xanthomonas oryzae pv. oryzicola in southern China. (Abstr.) Phytopathology 100:S96.

22. Perrier, X., Flori, A., and Bonnot, F. 2003. Data analysis methods. Pages 43-76 in: Genetic Diversity of Cultivated Tropical Plants. P. Hamon, M. Seguin, X. Perrier, and J. C. Glaszmann, eds. Enfield, Science Publishers, Montpellier, France.

23. Pourcel, C., Minandri, F., Hauck, Y., D'Arezzo, S., Imperi, F., Vergnaud, G., and Visca, P. 2011. Identification of variable-number tandem-repeat (VNTR) sequences in Acinetobacter baumannii and interlaboratory validation of an optimized multiple-locus VNTR analysis typing scheme. J. Clin. Microbiol. 49:539-548.

24. Pruvost, O., Vernière, C., Vital, K., Guérin, F., Jouen, E., Chiroleu, F., AhYou, N., and Gagnevin, L. 2011. Insertion sequence- and tandem repeatbased genotyping techniques for Xanthomonas citri pv. mangiferae indicae. Phytopathology 101:887-893. 
25. Qu, W., Shen, Z., Zhao, D., Yang, Y., and Zhang, C. 2009. MFEprimer: Multiple factor evaluation of the specificity of PCR primers. Bioinformatics 25:276-278.

26. Raymundo, A. K., Briones, A. M., Jr., Ardales, E. Y., Perez, M. T., Fernandez, L. C., Leach, J. F., Mew, T. W., Ynalvez, M. A., McLaren, C. G., and Nelson, R. J. 1999. Analysis of DNA polymorphism and virulence in Philippine strains of Xanthomonas oryzae pv. oryzicola. Plant Dis. 83:434-440.

27. Simpson, A. J., Reinach, F. C., Arruda, P., Abreu, F. A., Acencio, M., Alvarenga, R., Alves, L. M., Araya, J. E., Baia, G. S., Baptista, C. S., Barros, M. H., Bonaccorsi, E. D., Bordin, S., Bové, J. M., Briones, M. R., Bueno, M. R., Camargo, A. A., Camargo, L. E., Carraro, D. M., Carrer, H., Colauto, N. B., Colombo, C., Costa, F. F., Costa, M. C., Costa-Neto, C. M., Coutinho, L. L., Cristofani, M., Dias-Neto, E., Docena, C., ElDorry, H., Facincani, A. P., Ferreira, A. J., Ferreira, V. C., Ferro, J. A., Fraga, J. S., França, S. C., Franco, M. C., Frohme, M., Furlan, L. R., Garnier, M., Goldman, G. H., Goldman, M. H., Gomes, S. L., Gruber, A., Ho, P. L., Hoheisel, J. D., Junqueira, M. L., Kemper, E. L., Kitajima, J. P., Krieger, J. E., Kuramae, E. E., Laigret, F., Lambais, M. R., Leite, L. C., Lemos, E. G., Lemos, M. V., Lopes, S. A., Lopes, C. R., Machado, J. A., Machado, M. A., Madeira, A. M., Madeira, H. M., Marino, C. L., Marques, M. V., Martins, E. A., Martins, E. M., Matsukuma, A. Y., Menck, C. F., Miracca, E. C., Miyaki, C. Y., Monteriro-Vitorello, C. B., Moon, D. H., Nagai, M. A., Nascimento, A. L., Netto, L. E., Nhani, A., Jr., Nobrega, F. G., Nunes, L. R., Oliveira, M. A., de Oliveira, M. C., de Oliveira, R. C., Palmieri, D. A., Paris, A., Peixoto, B. R., Pereira, G. A., Pereira, H. A., Jr., Pesquero, J. B., Quaggio, R. B., Roberto, P. G., Rodrigues, V., de M Rosa, A. J., de Rosa, V. E., Jr., de Sá, R. G., Santelli, R. V., Sawasaki, H. E., da Silva, A. C., da Silva, A. M., da Silva, F. R., da Silva, W. A., Jr., da Silveira, J. F., Silvestri, M. L., Siqueira, W. J., de Souza, A. A., de Souza, A. P., Terenzi, M. F., Truffi, D., Tsai, S. M., Tsuhako, M. H., Vallada, H., Van Sluys, M. A., Verjovski-Almeida, S., Vettore, A. L., Zago, M. A., Zatz, M., Meidanis, J., and Setubal, J. C. 2000. The genome sequence of the plant pathogen Xylella fastidiosa. Nature 406:151-159.

28. Sola, C., Ferdinand, S., Mammina, C., Nastasi, A., and Rastogi, N. 2001. Genetic diversity of Mycobacterium tuberculosis in Sicily based on spoligotyping and variable number of tandem DNA repeats and comparison with a spoligotyping database for population-based analysis. J. Clin. Microbiol. 39:1559-1565.

29. Stall, R. E., and Civerolo E. L. 1991. Research relating to the recent outbreak of citrus canker in Florida. Annu. Rev. Phytopathol. 29:399-420.

30. Tang, D., Wu, W., Li, W., Lu, H., and Worland, A. J. 2000. Mapping of QTLs conferring resistance to bacterial leaf streak in rice. Theor. Appl. Genet. 101:286-291.

31. Triplett, L. R., Hamilton, J. P., Buell, C. R., Tisserat, N. A., Verdier, V., Zink, F., and Leach, J. E. 2011. Genomic analysis of Xanthomonas oryzae isolates from rice grown in the United States reveals substantial divergence from known X. oryzae pathovars. Appl. Environ. Microbiol. 77:3930-3937.

32. van Belkum, A. 2007. Tracing isolates of bacterial species by multi locus variable number of tandem repeat analysis (MLVA). FEMS Immunol. Med. Microbiol. 49:22-27.

33. van Belkum, A., Scherer, S., van Leeuwen, W., Willemse, D., van Alphen, L., and Verbrugh, H. 1997. Variable number of tandem repeats in clinical strains of Haemophilus influenzae. Infect. Immun. 65:5017-5027.

34. Vergnaud, G., and Pourcel, C. 2009. Multiple locus variable number of tandem repeats analysis. Methods Mol. Biol. 551:141-158.

35. Wonni, I., Detemmerman, L., Dao, S., Ouedraogo, L., Soungalo, S., Koita, Szurek, B., Koebnik, R., Triplett, T., Cottyn, B., and Verdier, V. 2011. Genetic diversity of Xanthomonas oryzae pv. oryzicola from West Africa. (Abstr.) Phytopathology 101:S193.

36. Wonni, I., Ouedraogo, L., and Verdier, V. 2010. First report of bacterial leaf streak caused by Xanthomonas oryzae pv. oryzicola on rice in Burkina Faso. Plant Dis. 95:72.

37. Zhao, B., Ardales, E., Brasset, E., Claflin, L. E., Leach, J. E., and Hulbert S. H. 2004. The Rxol/Rbal locus of maize controls resistance reactions to pathogenic and non-host bacteria. Theor. Appl. Genet. 109:71-79.

38. Zhao, B., Ardales, E. Y., Raymundo, A., Bai, J., Trick, H. N., Leach, J. E., and Hulbert, S. H. 2004. The avrRxol gene from the rice pathogen Xanthomonas oryzae pv. oryzicola confers a nonhost defense reaction on maize with resistance gene Rxo1. Mol. Plant-Microbe Interact. 17:771779.

39. Zhao, B. Lin, X. Poland, J., Trick, H., Leach, J., and Hulbert S. H. 2005. A maize resistance gene functions against bacterial streak disease in rice. Proc. Natl. Acad. Sci. USA 102:15383-15388. 